\title{
Performance and carcass traits of Santa Inês lambs finished with different sources of forage
}

\section{Adriana Morato Menezes ${ }^{1}$, Helder Louvandini ${ }^{2}$, Geisa Isilda Ferreira Esteves ${ }^{1}$, Luciana Dalcin ${ }^{1}$, Maria Eugênia Andrighetto Canozzi ${ }^{3}$, Júlio Otávio Jardim Barcellos ${ }^{3}$, Concepta McManus ${ }^{3}$}

\footnotetext{
1 Pós-graduação em Ciências Animais, Universidade de Brasília, Brasília, DF, Brazil, 70910-900.

${ }^{2}$ Centro de Energia Nuclear na Agricultura, Av. Centenário n 303, Caixa Postal 96, Piracicaba, SP, Brazil, 13416-000.

${ }^{3}$ Departamento de Zootecnia, UFRGS, Av. Bento Gonçalves no 7712, Porto Alegre, RS, Brazil, 91540-000.
}

\begin{abstract}
The objective of this study was to evaluate performance and biometrics of lambs fed different sources of forage. Twenty-four six-month-old Santa Inês female lambs were randomly allocated to four experimental diets and housed in individual stalls. They weighed on average $26.35 \pm 0.20 \mathrm{~kg}$. The diets were coast cross hay (HAY), cassava hay (CAS), dehydrated by-product of pea crop (PEA) and saccharin (SAC). The diets were formulated with the same amount of protein and energy with fixed levels of forage (60\%) and concentrate (40\%). Adaptation to the diet took 7 days, with 45 days on experiment. Weights and biometric measurements were obtained every fortnight and feed intake three times a week. Rights half-carcasses were weighed and sectioned into retail cuts, rib, loin, shoulder, belly, neck and leg, which were weighed individually. Weight gain in lambs was significantly different between diets, with those fed saccharin gaining more. Overall, treatments did not significantly affect biometric measurements. There was a significant difference for feed intake and live weight at the end of the experiment. Animals fed PEA and SAC showed the best results. Average positive correlations were found between biometric measurements and live weight. Treatment PEA had heavier hot $(14.36 \mathrm{~kg})$ and cold $(14.01 \mathrm{~kg})$ carcass weights than the other groups. Hot carcass kill-out was higher for animals fed PEA as well as ham weight, belly, neck and heart girth. The weight of the abdominal viscera (\%) for lambs fed CAS was greater than those fed SAC and PEA. The weights of the thoracic viscera as well as the liver, for lambs fed PEA were higher. The by-product of pea yielded best results, followed by saccharin, and can replace traditional forage sources in the region, providing similar results in terms of cuts and body components. These could be an alternative for feeding sheep in the dry season. The substitution of forages using by-product of pea and saccharin led to improved productivity over the coast-cross hay available in the Federal District - Brazil.
\end{abstract}

Key Words: carcass, cassava, hay, pea, sheep, sugar cane

\section{Introduction}

Sheep production in Brazil is characterized by the need for standardized and differentiated products, and is affected by the quality of the product and speed with which the various parts in the production chain can exchange information: farmer, slaughterhouse, retail and institutional and consumer markets (Souza, 2006). According to Souza et al. (2004), productivity is low, in part due to seasonality in forage production and the frequent changes in prices of grains and protein supplements used in animal feed.

The peculiarities of climate, pasture degradation, low carrying capacity of native vegetation and the quality of forage available in the dry season are obstacles to providing a balanced diet for the animals (Nunes et al., 2007). The use of agro-industrial by-products or crop residues represents important feed resources for sheep in the period of fodder scarcity (Souza et al., 2004; Nunes et al., 2007). Pelizer (2007) found that by-products may contain many substances of high nutritional value, and, by applying the appropriate technology, can be converted into commercial products or raw materials for secondary processes.

The agro-industries installed in the Federal District, Brazil and its surroundings offer numerous byproducts from cassava and other crops, minimally processed fruits and vegetables, seeds and grains, tomatoes, sweet corn, as well as products for bakeries and breweries. The use of by-products of these industries is increasing and they can be used as components of animal feed, mainly for semiconfined and confined ruminants, helping to reduce costs (Nunes et al., 2007).

It is known that feed is the single most important item responsible for the largest percentage of total production costs in sheep in this region of Brazil (Paim et al., 2011). To reduce these, without changing the animal performance or product quality, there is a real need to seek alternative 
sources of energy to make farms more competitive, generating positive revenue for the farmer. The objective of this study was to evaluate the alternative forages for feeding sheep during the dry period in the Federal District of Brazil.

\section{Material and Methods}

Twenty-four six-month-old female Santa Ines (hair breed) lambs were used. The nimals were divided randomly into four groups of six animals each. The average weight was $26.35 \pm 0.20 \mathrm{~kg}$. They were identified, weighed and dewormed with levamisole hydrochloride at $5 \%$. Animals were housed in a covered shed, in individual $1.50 \mathrm{~m}^{2}$ stalls equipped with individual feeders and water troughs. Lambs were adapted to the diet for seven days before the beginning of evaluations, which lasted 45 days.

Lambs were fed four different diets formulated with the same amount of protein and energy, depending on the by-product used. There were fixed proportions of roughage $(60 \%)$ and concentrate (40\%): HAY - coast-cross hay (Cynodon dactylon) (control); PEA - by-product of the dried pea crop (Pisum sativum); CAS - hay made of shoots of cassava plant (Manihot esculenta); and SAC - saccharin (Saccharum ssp.). These by-products are of regional origin. The stem, petiole and leaf of cassava were used to make the CAS hay. Adapting the methodology of Elias (1990), the saccharin was obtained from the stem and leaves of sugarcane (Saccharum spp.).

Concentrate was offered daily, as well as two grams of dicalcium phosphate to provide calcium and phosphorus. Feed and water were supplied twice a day: at $8 \mathrm{~h} 30$ and $17 \mathrm{~h} 30$ and the diet was balanced according to the recommendations of the National Research Council (NRC, 2006), with intake calculated as $3 \%$ of body weight. The feed leftovers were collected three times per week and feed intake was calculated. The total diet (Table 2) began with $788 \mathrm{~g}$ /animal.day and gradually increased according to the feed intake, reaching $1,432 \mathrm{~g} /$ day.animal at the end of the experiment.

The chemical analysis was performed according to Silva \& Queiroz (2006) (Table 1).

The animals were weighed at the beginning (iLW) and end (eLW) of the experiment as well as every two weeks $(0,15,30$ and 45 days). Body measurements were obtained according to Osório et al. (1998) and Santana (2001) including height at withers (HW) and rump (HR), body length (BL), skin thickness (ST), leg circumference (LC), thorax circumference (TC), chest width (CW) and rump width (RW). The daily weight gain was calculated as follows: $\mathrm{ADG}=(\mathrm{iLW}-\mathrm{eLW}) / 45$ (kg/day). Body condition score (BCS) was obtained by palpation of the posterior dorsum of the animal and visual assessment by assigning scores ranging from 1 (very thin) to 5 (very fat).

Ultrasound measurements were obtained using an Aloka SSD-500 coupled to a linear transducer of $5 \mathrm{MH}$ including the length, height, the total area and width of the rib eye muscle and subcutaneous fat thickness. These measurements were performed two days before slaughter.

Animals were weighed before (eLW) and after (fLW) 24 hours of fasting. They were stunned using electric shock, bled and the blood was collected in a bucket. The thickness of skin fold was measured. During evisceration, skin; head; thoracic viscera: lung, heart and trachea; and abdominal organs: liver, kidneys, rumen, abomasum, reticulum, omasum and intestines were weighed. The

Table 1 - Chemical composition of experimental ingredients supplied to Santa Inês ewe lambs in the Federal District, Brazil

\begin{tabular}{|c|c|c|c|c|c|c|c|}
\hline Components & Dry matter (\%) & $\begin{array}{c}\text { Crude protein } \\
\qquad(\%)\end{array}$ & $\begin{array}{l}\text { Neutral detergent } \\
\text { fiber }(\%)\end{array}$ & $\begin{array}{l}\text { Acid detergent } \\
\text { fiber }(\%)\end{array}$ & $\begin{array}{c}\text { Ether extract } \\
(\%)\end{array}$ & $\begin{array}{c}\text { Mineral matter } \\
(\%)\end{array}$ & $\begin{array}{c}\text { Total digestible } \\
\text { nutrients }(\%)\end{array}$ \\
\hline Coast-cross hay & 87.64 & 5.72 & 69.05 & 38.22 & 1.28 & 3.36 & 53.12 \\
\hline By-product of dried pea & 91.02 & 17.10 & 61.79 & 46.24 & 2.30 & 8.13 & 41.25 \\
\hline Hay made of cassava plant shoots & 91.67 & 10.11 & 66.86 & 48.07 & 8.79 & 5.62 & 32.57 \\
\hline Saccharin & 92.87 & 9.82 & 58.38 & 42.99 & 3.88 & 3.43 & 46.05 \\
\hline Corn & 88.00 & 9.30 & 57.00 & 32.00 & 4.30 & & 80.00 \\
\hline Soybean meal & 89.00 & 45.00 & & & 0.90 & & 73.00 \\
\hline
\end{tabular}

Values expressed in \% of dry matter.

Table 2 - Composition of experimental diets fed to Santa Inês ewe lambs in the Federal District, Brazil

\begin{tabular}{lcccc}
\hline Item & Coast-cross hay & By-product of dried pea & Hay made of cassava plant shoots & Saccharin \\
\hline Forage (\%) & 60 & 60 & 60 & 60 \\
Corn grain (\%) & 11.24 & 24.10 & 19.08 & 16.59 \\
Soybean meal (\%) & 28.76 & 15.90 & 20.92 & 23.48 \\
\hline
\end{tabular}

Values expressed in \%. 
stomach compartments, full and empty intestines and liver were weighed individually. The hot carcass weight (HCW) was obtained after weighing the carcasses.

The content of the gastrointestinal (GI) tract was calculated by the difference between full and empty stomach weights. The calculation of individual cuts was done as a percentage of body components based on final body weight. The $\mathrm{pH}$ was measured after slaughter (ipH) on the hot carcass and after 24 hours in the refrigerator at $1{ }^{\circ} \mathrm{C}(\mathrm{fpH})$.

The carcasses were evaluated by assigning subjective scores, ranging from 1 (very thin) to 5 (very fat) according to the degree distribution and accumulation of fat in the carcass. The carcass length was measured. The true yield, or yield of hot carcass was calculated as $\mathrm{TY}=\mathrm{HCW} / \mathrm{eLW} * 100$ and empty body weight as true kill-out: $\mathrm{TKO}=\mathrm{eLW}-\mathrm{GI}$.

The carcasses were chilled to $1{ }^{\circ} \mathrm{C}$ for 24 hours in a cold room. The cold carcass weight (CCW) was used for the calculation of weight loss by cooling (WLC $=\mathrm{HCW}$ $\left.\mathrm{CCW} / \mathrm{HCW}^{*} 100\right)$ and cold carcass kill-out or commercial yield $\left(\mathrm{CCKO}=\mathrm{CCW} / \mathrm{LWAF}^{*} 100\right)$. The carcasses were evaluated as proposed by Müller (1980) based on objective (weights and measurements) and subjective (conformation) measures.

The carcasses were split lengthwise along the spine. The right half-carcasses (RHC) were weighed and sectioned in areas designated as commercial cuts, according to Silva Sobrinho (2001): rib, loin, shoulder, ham, neck and leg, which were weighed individually. The leg length (LL) and perimeter (LP) were recorded. The percentage yield of commercial cuts based on the half-carcass yield was calculated.

The 12th rib was separated to measure the rib eye area (REA), using a transparent $1 \mathrm{~cm}^{2}$ grid. The height and width of the rib eye muscle were measured with a ruler. Fat thickness was assessed using precision calipers.
The experimental design was completely randomized with 4 treatments (diets). Using the statistical program Statistical Analysis System (SAS, version 9.3), the variables were analyzed with procedures MIXED (analysis of variance) and CORR (correlation). Means were compared using the Duncan test $(\mathrm{P}<0.05)$.

\section{Results and Discussion}

The different diets did not influence the measurements taken (iLW, BCS, BL, HR, TC, LC, RW and ST), except for HW and $\mathrm{CW}(\mathrm{P}<0.05)$, while the time on experiment influenced $\mathrm{LW}, \mathrm{HW}, \mathrm{HR}, \mathrm{TC}, \mathrm{RW}$ and $\mathrm{CW}$. There was an interaction between diet and time for the DC and ST. The initial weight did not differ between treatments, but during the experiment there were changes in the weights of the animals (Table 3 ). The animals gained weight even though the experiment was carried out in the dry season. This is a period associated with food shortages and weight loss (Menezes, 2006).

Body condition score (BCS) of animals fed SAC was higher and differed $(\mathrm{P}<0.05)$ from the HAY group. This may be a reflection of the digestibility of diets, since, according to Maior Júnior et al. (2008), SAC has higher energy availability, with higher levels of soluble sugars, resulting in greater accumulation of fat in the lambs.

The height at the withers (HW) was significantly higher in treatment CAS compared with HAY. The hay diet with cassava shoots had the highest NDF content (66.86\%).

Height at the rump did not differ between diets, but decreased over the experimental period. Yáñez et al. (2004) observed a decrease in the width of the back of $21 \mathrm{~kg}$ Sannen goats due to development of bone associated with muscle, typical of females. This may be a reflection of converting animal fat into energy for growth. The chest width (CW) of

Table 3 - Summary of analysis of variance and growth of Santa Ines lambs

\begin{tabular}{|c|c|c|c|c|c|c|c|c|c|c|}
\hline & iLW (kg) & $\mathrm{BCS}$ & $\mathrm{BL}(\mathrm{cm})$ & $\mathrm{HW}(\mathrm{cm})$ & $\mathrm{HR}(\mathrm{cm})$ & $\mathrm{TC}(\mathrm{cm})$ & $\mathrm{LC}(\mathrm{cm})$ & $\mathrm{RW}(\mathrm{cm})$ & $\mathrm{CW}(\mathrm{cm})$ & $\mathrm{ST}(\mathrm{cm})$ \\
\hline $\mathrm{R}^{2}$ & 0.32 & 0.20 & 0.25 & 0.30 & 0.28 & 0.22 & 0.44 & 0.38 & 0.45 & 0.21 \\
\hline $\mathrm{CV} \%$ & 8.35 & 9.87 & 4.78 & 4.91 & 4.10 & 4.23 & 6.65 & 8.18 & 9.55 & 15.77 \\
\hline Mean & 28.60 & 2.91 & 63.31 & 63.89 & 69.74 & 70.33 & 33.36 & 18.88 & 19.58 & 0.39 \\
\hline Diet & NS & NS & NS & $*$ & NS & NS & NS & NS & $*$ & NS \\
\hline Days & $* * *$ & $*$ & NS & $* * *$ & $* * *$ & $* * *$ & $* *$ & $* * *$ & $* * *$ & $\mathrm{P}=0.08$ \\
\hline Diet $\times$ days & NS & NS & $*$ & NS & NS & NS & NS & $\mathrm{P}=0.06$ & NS & $* * *$ \\
\hline \multicolumn{11}{|c|}{ Means per treatment } \\
\hline HAY & $28.40 \mathrm{a}$ & $2.78 b$ & $62.94 \mathrm{a}$ & $62.85 \mathrm{~b}$ & $69.52 \mathrm{a}$ & $69.40 \mathrm{a}$ & $33.21 \mathrm{a}$ & $18.58 \mathrm{a}$ & $19.16 \mathrm{a}$ & $0.38 \mathrm{a}$ \\
\hline PEA & $29.42 \mathrm{a}$ & $2.94 \mathrm{a}$ & $62.48 \mathrm{a}$ & $63.44 \mathrm{ab}$ & $69.48 \mathrm{a}$ & $70.10 \mathrm{a}$ & $33.63 \mathrm{a}$ & $18.85 \mathrm{a}$ & $19.29 b$ & $0.38 \mathrm{a}$ \\
\hline CAS & $28.35 \mathrm{a}$ & $2.89 \mathrm{ab}$ & $63.77 \mathrm{a}$ & $64.88 \mathrm{a}$ & $70.54 a$ & $70.70 \mathrm{a}$ & $32.83 a$ & $18.75 \mathrm{a}$ & $19.60 \mathrm{ab}$ & $0.39 \mathrm{a}$ \\
\hline SAC & $28.21 \mathrm{a}$ & $3.04 \mathrm{a}$ & $64.06 \mathrm{a}$ & $64.40 \mathrm{ab}$ & $69.44 \mathrm{a}$ & $70.58 \mathrm{a}$ & $33.79 a$ & $19.33 a$ & $20.27 \mathrm{a}$ & $0.39 \mathrm{a}$ \\
\hline
\end{tabular}

Means with different letters in a column differ $(\mathrm{P}<0.05)$ according to Duncan's test at $5 \%$.

$* \mathrm{P}<0.05 ; * * \mathrm{P}<0.01 ; * * * \mathrm{P}<0.001$

iLW - initial weight; BCS - body condition score with a subjective evaluation score of 1-5; BL - body length; HW - height at the withers; HR - height at rump; TC - thorax circumference; LC - leg circumference; RW - rump width; CW - chest width; ST - skin thickness; NS - not significant.

$\mathrm{CV}$ - coefficient of variation; HAY - coast-cross hay; PEA - by-product of dried pea; CAS - hay made of cassava plant shoots; SAC - saccharin. 
animals fed SAC was higher $(\mathrm{P}<0.05)$ compared with the PEA group. This may be due to quicker fattening of sheep on saccharin.

Costa Júnior et al. (2006), in a study of Santa Inês sheep at different ages (up to one year of age), found values close to those found in this study: average weights of $39.0 \pm 12.7 \mathrm{~kg}$, with BL $69.4 \pm 6.3 \mathrm{~cm}$, HW $69.4 \pm 6.1 \mathrm{~cm}$, HR $69.7 \pm 6.6 \mathrm{~cm}$, and TC $79.4 \pm 8.5 \mathrm{~cm}$. Gusmão Filho et al. (2009) points out that body measurements of Santa Inês sheep may be associated with factors related to general and sexual development.

Medium positive correlations were found between the biometric measurements and between these measures and body weight. This is in agreement with results obtained in sheep and cattle by Santos (2000), Rocha et al. (2003) and Costa Júnior et al. (2006). The correlation between RW and days on treatment was negative $(-0.43)$, showing that this decreased with time, probably due to the use of fat for growth. The trend of increased width of rump is a desired trait in females, since it is highly correlated with milk production. In contrast, Mello \& Schmidt (2008), working with Anglo-Nubian goats, found a significant linear increase in this measure over time, and an inverse trend for measures of thoracic perimeter and abdominal girth.

Diets and iLW did not affect $(\mathrm{P}>0.05)$ eLW or fLW. Bdoy length, HW and HR were statistically different $(\mathrm{P}<0.05)$ between treatments groups. Diet significantly affected ADG, total weight gain (TWG), feed intake (FI) and TC (Table 4). Rump width was affected by iLW since width is a measure of muscle development and may reflect the greater conversion of energy for growth, rather than muscle deposition. Rump width differed between diets, with PEA and HAY having higher means $(\mathrm{P}<0.05)$ than CAS and SAC, probably due to increased deposition of fat. The quality of the coast-cross hay, the availability of protein and lower NDF in the byproduct of the dried pea crop may have influenced this.

Costa Júnior et al. (2006) found differences in rump width $(19.6 \pm 2.4 \mathrm{~cm})$, which was $6 \%$ higher in males. Cunha et al. (2000), in an experiment with Santa Ines lambs slaughtered at $32 \mathrm{~kg}$, found a hip width of $19.1 \mathrm{~cm}$. Both obtained values higher than this study, probably because they were heavier, higher iLW and because of the diet used. The lambs fed SAC had highest feed intake ( $1.63 \mathrm{~kg} /$ day), and the other diets were similar. This led to higher weight gain over the period. The CAS group intake was affected by low digestibility and high NDF of this diet. The latter diet, according to Carvalho et al. (2006), has a low degradability with a slow rate of passage (65\% approximately in 24 hours).

Average BCS for SAC (3.29) was higher and differed significantly from other diets, which may be a reflection of digestibility of the diet. Maior Júnior et al. (2008) showed that SAC would have greater energy availability, with higher levels of soluble sugars, resulting in greater accumulation of fat in lambs.

Significant differences were found for ADG between treatments $(\mathrm{P}<0.05)$, below the $0.2 \mathrm{~kg}$ /day expected from the initial formulation of the diet (NRC, 2006). The diet with saccharin had the highest value and differed significantly from the others. This may be due to the low digestibility of the CAS and the high concentration of soluble sugars and addition of urea in SAC.

Araújo et al. (2004) conducted a study with maniçoba (manioc) hay and also found ADG values lower than expected $(0.044 \mathrm{~kg} /$ day $)$. These authors showed that weight gain was not influenced by the levels of this byproduct, but by low intake of energy and protein, by animal type and

Table 4 - Summary of analysis of variance of Santa Inês lambs for body traits on experimental diets

\begin{tabular}{|c|c|c|c|c|c|c|c|c|c|c|c|c|c|}
\hline & $\begin{array}{c}\text { ADG } \\
(\mathrm{kg})\end{array}$ & $\begin{array}{l}\text { FI } \\
(\mathrm{kg})\end{array}$ & $\begin{array}{l}\text { eLW } \\
(\mathrm{kg})\end{array}$ & $\begin{array}{l}\text { fLW } \\
(\mathrm{kg})\end{array}$ & BCS & $\begin{array}{c}\mathrm{BL} \\
(\mathrm{cm})\end{array}$ & $\begin{array}{l}\mathrm{HW} \\
(\mathrm{cm})\end{array}$ & $\begin{array}{l}\text { HR } \\
(\mathrm{cm})\end{array}$ & $\begin{array}{c}\mathrm{TC} \\
(\mathrm{cm})\end{array}$ & $\begin{array}{l}\mathrm{LC} \\
(\mathrm{cm})\end{array}$ & $\begin{array}{l}\mathrm{RW} \\
(\mathrm{cm})\end{array}$ & $\begin{array}{l}\mathrm{CW} \\
(\mathrm{cm})\end{array}$ & $\begin{array}{l}\mathrm{ST} \\
(\mathrm{cm})\end{array}$ \\
\hline $\mathrm{R}^{2}$ & 0.37 & 0.96 & 0.73 & 0.77 & 0.52 & 0.06 & 0.03 & 0.06 & 0.24 & 0.14 & 0.51 & 0.11 & 0.27 \\
\hline $\mathrm{CV} \%$ & 62.43 & 1.16 & 4.52 & 4.7 & 6.46 & 3.85 & 4.53 & 5.07 & 3.32 & 4.32 & 10.95 & 12.97 & 16.17 \\
\hline Diet & * & $* * *$ & NS & ** & * & NS & NS & NS & NS & NS & NS & NS & NS \\
\hline iLW & NS & $* * *$ & $*$ & NS & NS & $* *$ & $* * *$ & $* * *$ & $*$ & NS & $* * *$ & NS & NS \\
\hline \multicolumn{14}{|c|}{ Means per treatment } \\
\hline PEA & $0.053 \mathrm{ab}$ & $1.58 \mathrm{a}$ & $30.91 \mathrm{a}$ & $29.61 \mathrm{a}$ & $3.00 \mathrm{~b}$ & $61.00 \mathrm{a}$ & $65.58 \mathrm{a}$ & $71.58 \mathrm{a}$ & $72.33 \mathrm{a}$ & $36.41 \mathrm{a}$ & $17.25 \mathrm{a}$ & $20.91 \mathrm{a}$ & $3.68 \mathrm{a}$ \\
\hline CAS & $0.017 \mathrm{a}$ & $1.59 \mathrm{a}$ & $29.23 a$ & $27.31 \mathrm{~b}$ & $2.95 b$ & $59.83 \mathrm{a}$ & $66.50 \mathrm{a}$ & $73.00 \mathrm{a}$ & $70.91 \mathrm{a}$ & $35.41 \mathrm{a}$ & $14.5 \mathrm{~b}$ & $22.58 \mathrm{a}$ & $3.03 \mathrm{a}$ \\
\hline SAC & $0.075 \mathrm{~b}$ & $1.63 \mathrm{~b}$ & $30.23 a$ & $29.26 \mathrm{a}$ & $3.29 \mathrm{a}$ & $60.75 \mathrm{a}$ & $65.83 \mathrm{a}$ & $70.66 \mathrm{a}$ & $71.41 \mathrm{a}$ & $35.41 \mathrm{a}$ & $13.66 \mathrm{~b}$ & $22.58 \mathrm{a}$ & $3.23 \mathrm{a}$ \\
\hline
\end{tabular}

Means with different letters in a column differ $(\mathrm{P}<0.05)$, according to Duncan test at $5 \%$.

$* \mathrm{P}<0.05 ; * * \mathrm{P}<0.01 ; * * * \mathrm{P}<0.001$.

ADG - average daily gain; FI - feed intake; eLW - weight at end of experiment; fLW - weight after fasting; BCS - body condition score with a subjective evaluation score of 1-5; BL - body length; HW - height at the withers; HR - rump height; TC - thorax circumference; LC - leg circumference; RW - rump width; CW - width of the chest; ST - skin thickness; NS - not significant.

CV - coefficient of variation; HAY - coast-cross hay; PEA - by-product of dried pea; CAS - hay made of cassava plant shoots; SAC - saccharin. 
confinement conditions. Garcia et al. (1990) and Ruiz et al. (1990), in a study with lambs comparing the replacement of grain by SAC, found that SAC can be included at up to $70 \%$ in the diet, without affecting performance.

The treatments did not significantly affect eLW $(\mathrm{P}>0.05)$, but there was a significant effect $(\mathrm{P}<0.05)$ on FLW. The diet with saccharin and CAS had, respectively, lower and higher weight loss due to 24 hours of fasting. This result may be due to the characteristics of the PAM diet having high content of NDF, causing the food to remain longer in the gastrointestinal tract, accentuating the difference in weight after a 24-hour fast.

Final live weight had a high positive correlation with FLW (0.97), TC (0.72) and FI (0.65), which is consistent with Campelo et al. (2002). Moreover, animals with higher final weight consumed more feed and had higher chest girth and BCS, indicating greater fat deposition. Silva et al. (2008), in an experiment with male Morada Nova lambs fed increasing levels of silk flower in the diet, found an average positive correlation $(0.55)$ for body condition score and live weight at slaughter.

Significant differences $(\mathrm{P}<0.05)$ between treatments were found for fat cover and height of REA measured by ultrasound (Table 5), with the lowest value found for CAS. This result may be related to age and weight at slaughter, as fat deposition was in an accelerated phase at the time of slaughter, which is earlier in females than in males. Fat cover is a subjective measure, making it difficult to measure and compare between studies. Final live weight influenced skin thickness total area and the height measured by ultrasound $(\mathrm{P}<0.05)$.

Landim et al. (2011), in a study with male and female crossbred Santa Inês at different slaughter weights, found values for fat thickness for females slaughtered at $30 \mathrm{~kg}$ close to those found in this study. Cardoso (2008), working with different breed groups and slaughter weights, obtained FI between 3.61 and 3.42 for female Santa Ines animals. Landim et al. (2007) found 2.77; Bueno et al. (2001), 1.82; and Furusho-Garcia et al. (2003) found average of 2.4 for FI, i.e., all values were lower than this study.
Hot carcass weight, $\mathrm{CCW}$ and RHC were influenced by the treatments $(\mathrm{P}<0.05)$. Hot carcass weight values were higher for PEA, compared with HAY. Cold carcass weight was also highest for PEA and SAC and lowest for CAS. The animals fed PEA had heavier hot $(14.36 \mathrm{~kg}$ ) and cold carcass weights $(14.01 \mathrm{~kg})$ and half-carcass $(7.25 \mathrm{~kg})$ than SAC $(13.48,13.15$ and $6.68 \mathrm{~kg}$, respectively). This may have been due to the slow rate of passage of CAS in the gastrointestinal tract during the fasting period, thereby affecting body weight prior to slaughter, unlike PEA and SAC (Table 6).

With respect to kill-out, only hot carcass (HCKO) showed significant difference $(\mathrm{P}<0.05)$ between diets, with higher values found for animals fed PEA. Hot carcass kill-out, despite being within the range of values reported in the literature (Silva Sobrinho, 2001), can be considered medium to low, mainly due to the high weight of gastrointestinal contents. The animals fed CAS (lower than HCKO), after 24 hours fasting, still had $19.22 \%$ of the final body weight in their gastrointestinal tract. This is due to the low rate of passage of this diet, which has low digestibility (Magalhães et al., 2006).

Sañudo \& Sierra (1986) reported that kill-out is related to production per unit of weight and is variable in sheep (40-60\%) because of numerous intrinsic factors (Osório \& Osório, 2005) such as genotype, age, sex, type of delivery, degree of fat and weight, as well as extrinsic factors such as number of hours fasting, breeding system, feeding system, stress and cooling conditions. According to Silva \& Pires (2000), the highest yields of carcasses are found in young animals, due to growth of the gastrointestinal tract with increasing age and characteristics of the diet.

Cardoso (2008), working with Santa Inês and crossbred sheep, found that females $(48.25 \%)$ had higher hot carcass yields than males (45.87\%). Landim et al. (2007), in a study with crossbred animals, obtained maximum values of $39.60 \%$ to $38.40 \%$ for HCKO and cold carcass kill-out.

Loss by cooling did not differ between diets, which may be due to the degree of fat deposition in animals. Higher fat leads to lower loss of water during cooling (Silva Sobrinho, 1999), because of protection. Higher values were

Table 5 - Summary of analysis of variance for the sonographic characteristics in vivo and on Santa Ines lambs carcass

\begin{tabular}{|c|c|c|c|c|c|c|c|c|c|c|}
\hline Source of variation & $\mathrm{FC}$ & $\mathrm{ST}(\mathrm{cm})$ & $\operatorname{REAS}\left(\mathrm{cm}^{2}\right)$ & REHS (cm) & REWS (cm) & $\operatorname{REFS}(\mathrm{cm})$ & $\operatorname{REA}\left(\mathrm{cm}^{2}\right)$ & REH (cm) & $\mathrm{REW}(\mathrm{cm})$ & $\operatorname{REF}(\mathrm{cm})$ \\
\hline $\mathrm{R}^{2}$ & 0.47 & 0.27 & 0.21 & 0.18 & 0.17 & 0.43 & 0.18 & 0.43 & 0.25 & 0.46 \\
\hline $\mathrm{CV} \%$ & 7.80 & 16.17 & 14.35 & 18.85 & 9.66 & 36.33 & 13.45 & 7.39 & 8.00 & 36.33 \\
\hline Mean & 3.27 & 3.28 & 9.22 & 2.49 & 5.41 & 0.15 & 8.13 & 1.90 & 4.74 & 0.19 \\
\hline Diet & $* * *$ & NS & NS & NS & NS & NS & NS & $*$ & NS & NS \\
\hline eLW & NS & $* * *$ & $* * *$ & $* * *$ & NS & NS & NS & NS & NS & NS \\
\hline
\end{tabular}

$* \mathrm{P}<0.05 ; * * \mathrm{P}<0.01 ; * * * \mathrm{P}<0.001$

$\mathrm{CV}$ - coefficient of variation; eLW - weight at the end of experiment; NS - not significant.

FC - fat cover score 1-5; ST - skin thickness; REAS - rib eye area measured with ultrasound; REHS - height of rib eye area measured with ultrasound; REWS - width of the rib eye area measured with ultrasound; REFS - fat thickness of rib eye area measured with ultrasound; REA - rib eye area measured on carcass; REH - height of rib eye area measured on carcass; REW - width of rib eye area measured on carcass; REF - fat thickness of rib eye are measured on carcass. 
found by Dantas et al. (2008) and Cardoso (2008). The former found $4.18 \%$ in Santa Ines sheep on pasture without supplementation and $2.88 \%$ for supplemented animals on pasture, while the latter found $3.26 \%$ in confined Santa Ines females.

The different parts of the carcass have different economic values and their proportions are an important index for retail market assessment (Pilar et al., 2002). The literature indicates a wide variation in these values as a function of factors such as genetics, sex, body weight, diet and number of hours fasting (Miguélez et al., 2006; Cardoso, 2008). In the present study, the treatments affected $(\mathrm{P}<0.05)$ cuts: leg, neck and belly, as well as perimeter of shank. The final body weight (eLW) affected shoulder and rib weights, body length, as well as initial and final $\mathrm{pH}$ (Table 7).

The weight and perimeter of shank on PEA was higher $(\mathrm{P}<0.05)$ than for the other groups. The characteristics of this diet may have influenced these results, as it has higher quality (24.10\% in DM), and the energy was used to deposit fat and muscle. The ham is considered the noblest cut and has the highest amount of muscle tissue as compared with others. According to Bezerra et al. (2009), the better development of the posterior region with a greater weight of leg, when compared with the anterior region, is desirable in meat sheep.

Cardoso (2008), in a study with Santa Inês and crossbred females found averages of $2.65 \mathrm{~kg}$ for $1 \mathrm{eg}, 0.66 \mathrm{~kg}$ for back, $1.46 \mathrm{~kg}$ for the shoulder, $2.45 \mathrm{~kg}$ for rib and $0.85 \mathrm{~kg}$ to $0.56 \mathrm{~kg}$ for neck and belly. Landim et al. (2007) found values of $1.74,0.30,1.02$ and $1.43 \mathrm{~kg}$ for the cuts ham, loin, shoulder and rib, respectively, in Santa Ines sheep slaughtered at $30 \mathrm{~kg}$. Oliveira et al. (2002) showed averages for shoulder, loin and leg of $1.67,0.91$ and $3.08 \mathrm{~kg}$, respectively, in Santa Ines lambs fed pig manure.

One of the most striking aspects of the transformation of muscle into meat is a decrease in $\mathrm{pH}$, which determines the quality of the meat (Embrapa, 2009). This did not differ significantly between treatments. Oliveira et al. (2004), working with entire male Santa Inês lambs and different cooling temperatures, found $\mathrm{ipH}$ values of 6.67 and $\mathrm{fpH}$ of 5.61 .

With regard to the percentages of commercial cuts, no significant differences $(\mathrm{P}>0.05)$ were found between diets. The proportionality of growth in different regions of the carcass changed with body mass.

Table 6 - Summary of analysis of variance for the weight characteristics in vivo, slaughter and killout of lambs fed different diets

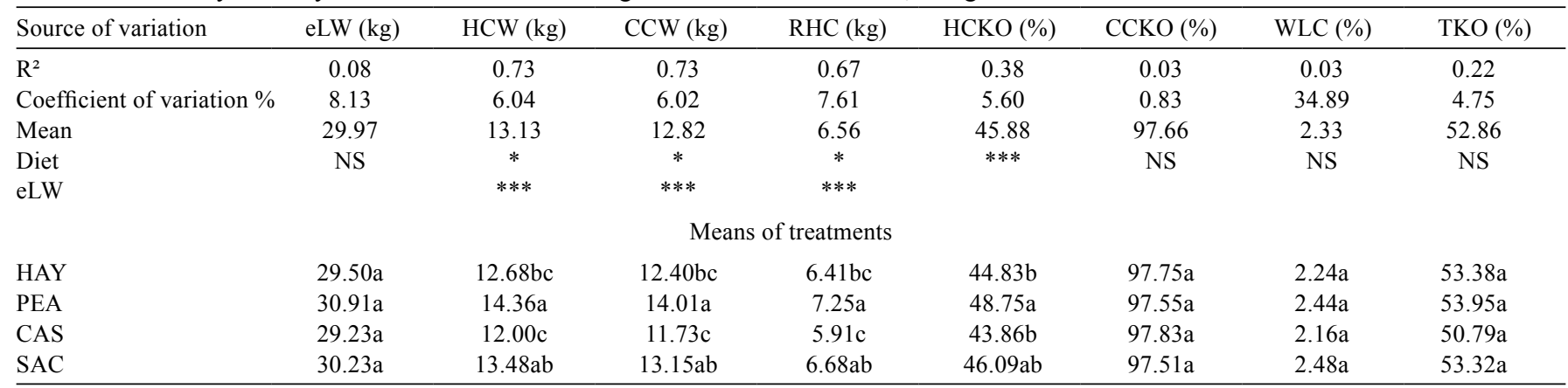

Means with different letters in a column differ $(\mathrm{P}<0.05)$ according to the Duncan test at $5 \%$.

$* \mathrm{P}<0.05 ; * * \mathrm{P}<0.01 ; * * * \mathrm{P}<0.001$.

NS - not significant; eLW - weight at end of experiment; HCW - hot carcass weight; CCW - cold carcass weight; RHC - right half-carcass weight; HCKO - hot carcass kill-out; CCKO - cold carcass kill-out; WLC - weight loss by cooling; TKO - true kill-out;

HAY - coast-cross hay; PEA - by-product of dried pea; CAS - hay made of cassava plant shoots; SAC - saccharin.

Table 7 - Summary of analysis of variance for carcass cuts in lambs

\begin{tabular}{|c|c|c|c|c|c|c|c|c|c|c|c|}
\hline & Leg $(\mathrm{kg})$ & $\mathrm{LL}(\mathrm{cm})$ & $\mathrm{LP}(\mathrm{cm})$ & Back (kg) & $\mathrm{BL}(\mathrm{cm})$ & Shoulder (kg) & Rib (kg) & Neck (kg) & Belly (kg) & $\mathrm{ipH}$ & $\mathrm{fpH}$ \\
\hline $\mathrm{R}^{2}$ & 0.45 & 0.07 & 0.35 & 0.16 & 0.06 & 0.14 & 0.25 & 0.44 & 0.51 & 0.15 & 0.09 \\
\hline $\mathrm{CV} \%$ & 9.08 & 4.59 & 3.30 & 18.78 & 3.85 & 14.09 & 12.00 & 15.72 & 22.42 & 5.68 & 4.92 \\
\hline Mean & 2.14 & 52.87 & 36.89 & 0.47 & 60.58 & 1.16 & 1.81 & 0.59 & 0.32 & 6.59 & 6.21 \\
\hline Diet & $*$ & NS & $* *$ & NS & NS & NS & NS & $*$ & $* *$ & NS & NS \\
\hline eLW & NS & NS & NS & NS & $* * *$ & $* *$ & $* * *$ & NS & NS & $*$ & $*$ \\
\hline \multicolumn{12}{|c|}{ Means of treatments } \\
\hline HAY & $2.07 \mathrm{~b}$ & $52.33 \mathrm{a}$ & $36.91 \mathrm{ab}$ & $0.46 \mathrm{a}$ & $60.75 a$ & $1.10 \mathrm{a}$ & $1.74 \mathrm{a}$ & $0.52 b$ & $0.26 \mathrm{c}$ & $6.53 \mathrm{a}$ & $6.15 \mathrm{a}$ \\
\hline PEA & $2.36 \mathrm{a}$ & $53.66 \mathrm{a}$ & $38.08 \mathrm{a}$ & $0.50 \mathrm{a}$ & $61.00 \mathrm{a}$ & $1.25 \mathrm{a}$ & $1.95 \mathrm{a}$ & $0.68 \mathrm{a}$ & $0.37 \mathrm{a}$ & $6.43 \mathrm{a}$ & $6.11 \mathrm{a}$ \\
\hline CAS & $2.05 \mathrm{~b}$ & $52.50 \mathrm{a}$ & $36.33 b$ & $0.42 \mathrm{a}$ & $59.83 a$ & $1.16 \mathrm{a}$ & $1.71 \mathrm{a}$ & $0.56 \mathrm{ab}$ & $0.28 b c$ & $6.80 \mathrm{a}$ & $6.25 \mathrm{a}$ \\
\hline $\mathrm{SAC}$ & $2.08 b$ & $53.00 \mathrm{a}$ & $36.25 b$ & $0.51 \mathrm{a}$ & $60.75 a$ & $1.14 \mathrm{a}$ & $1.83 \mathrm{a}$ & $0.61 \mathrm{ab}$ & $0.35 \mathrm{ab}$ & $6.60 \mathrm{a}$ & $6.32 \mathrm{a}$ \\
\hline
\end{tabular}

Means with different letters in a column differ $(\mathrm{P}<0.05)$ according to Duncan test at $5 \%$.

$* \mathrm{P}<0.05, * * \mathrm{P}<0.01, * * * \mathrm{P}<0.001$.

NS - not significant; eLW - weight at end of experiment; LL - leg length; LP - leg perimeter; BL - body length; ipH - initial pH; fpH - final pH.

$\mathrm{CV}$ - coefficient of variation; HAY - coast-cross hay; PEA - by-product of dried pea; CAS - hay made of cassava plant shoots; SAC - saccharin. 
The analysis of weights of body components (Table 8) is important not only because of the potential economic return, but also as a possible indirect nutritional assessment in the production of sheep for slaughter. Knowledge of sources of variation of these constituents can help in developing strategies to evaluate the effects of nutrition on growth and further optimize the use of various foods (Pereira et al., 2007).

The weight of the thoracic viscera for lambs fed PEA was the highest, representing $7.09 \%$ of final live weight $(\mathrm{P}<0.05)$. This may be a reflection of the availability of energy and protein in the diet. According to Louvandini et al. (2007), the viscera are developing earlier, and thus, tend to decrease in proportion with the evolution of body weight.

The weight of the abdominal viscera did not differ $(P>0.05)$ between treatments, but the yield was higher for lambs in the CAS group and differed statistically $(\mathrm{P}<0.05)$ from SAC. The treatments had different weights $(\mathrm{P}<0.05)$ for full rumen, the diet with the highest value $(4.30 \mathrm{~kg})$ was CAS, representing $14.83 \%$ of the final body weight, differing from PEA and SAC and PEA for percentages. This result could be attributed to CAS having a higher percentage of neutral detergent fiber (66.86\%) and thus less digestible fiber, spending more time in the rumen during the fasting period, and influencing body weight prior to slaughter.

Jardim et al. (2000) found that the more the gastric contents, the lower the digestibility of forage ingested by animals. This is also a determinant factor in carcass yield, which it is affected by speed of passage of the feed and fasting period (Queiroz et al., 2008). Araújo et al. (2004), using low-quality diets, observed that dry matter intake increased with increasing capacity of the rumen. However, they did not find the same correlations when using high quality diets, since larger animals have a higher intake capacity. So, with regards to the diets used in this experiment, especially CAS, the results in terms of final body weight and fasting body

Table 8 - Mean values for weights $(\mathrm{kg})$ and percentage (\%) of body components of lambs fed different diets

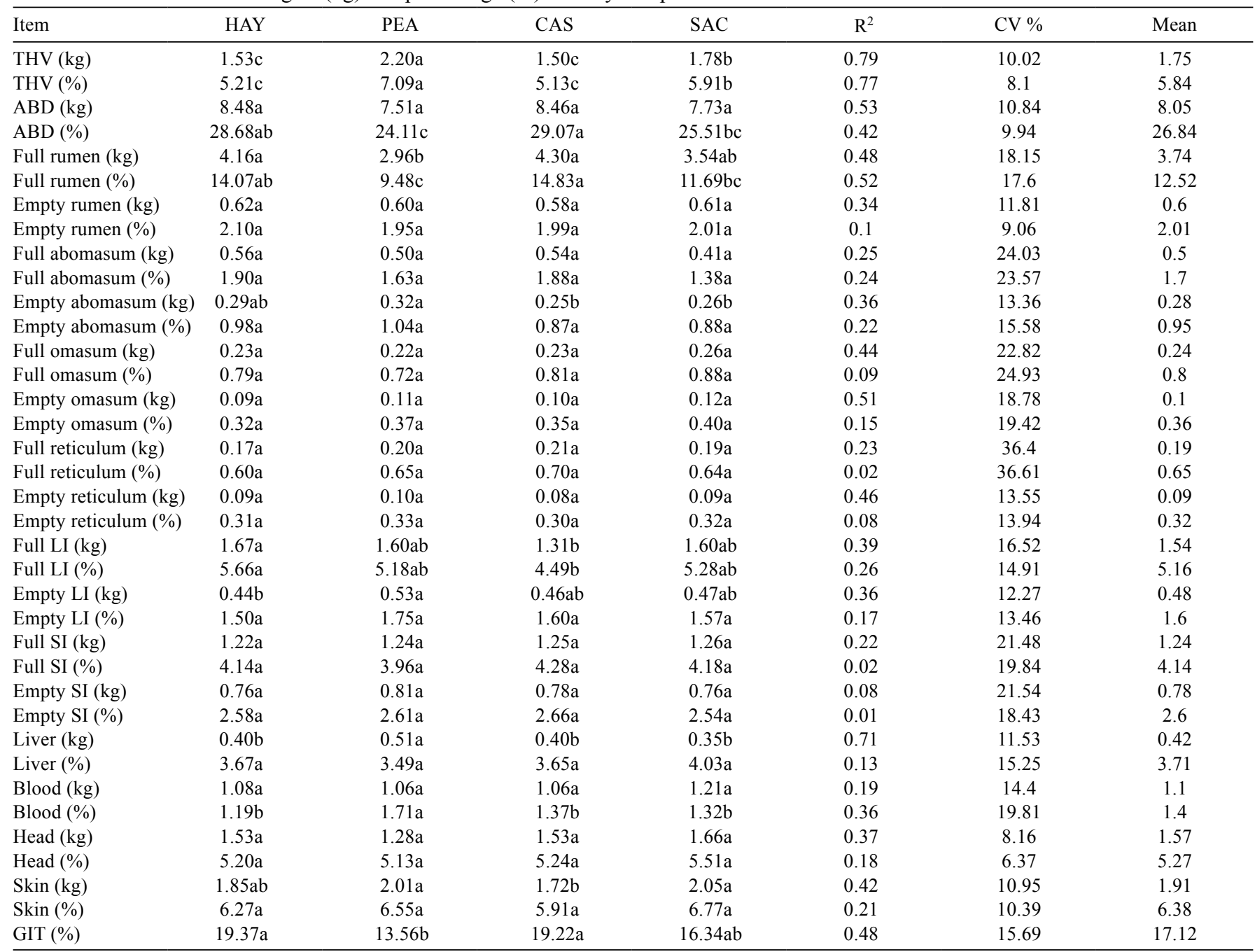

Means with different letters in a row differ $(\mathrm{P}<0.05)$ according to Duncan's test at $5 \%$.

THV - weight of the thoracic viscera; ABD - weight of the abdominal viscera; LI - large intestine; SI - small intestine; GIT - content of the gastrointestinal tract HAY - coast-cross hay; PEA - by-product of dried pea; CAS - hay made of cassava plant shoots; SAC - saccharin; CV - coefficient of variation. 
weight were expected, since the amount of material in the rumen was higher in this diet.

Diets did not influence $(\mathrm{P}>0.05)$ the full weight of the abomasum, since animals fed PEA had a higher empty abomasum weight $(\mathrm{P}<0.05)$. Peroni (1991) reported that most of this compartment is associated with greater feed intake and, consequently, higher nutrient input, as it actively participates in digestion and absorption. Fernandes et al. (2008), working with Suffolk sheep finished on pasture and confinement, found no significant differences caused by system in the weight of the head, skin, legs, rumen, lattice, abomasum, omasum and blood, but the intestine weights (1.622 and $2.25 \mathrm{~kg}$ for pasture and feedlot, respectively) showed differences between the systems.

For the weight of the large intestine, there were differences $(\mathrm{P}<0.05)$ between groups, with HAY having the highest $(1.67 \mathrm{~kg})$ and CAS the lowest value $(1.31 \mathrm{~kg})$. The differences between weight of the empty large intestine were significant $(\mathrm{P}<0.05)$, with highest weight for PEA $(0.53 \mathrm{~kg})$ and lowest for HAY $(0.44 \mathrm{~kg})$. The full and empty small intestine did not differ $(\mathrm{P}>0.05)$ in relation to diet. Figueiredo et al. (2006) and Carvalho et al. (2006) showed that CAS has a low degradability and slow passage rate: $65 \%$ in approximately 24 hours. The degradation rate can be influenced by dry matter, as well as cellular and soluble carbohydrate content.

Carvalho et al. (2005), working with crossbred animals with different levels of supplementation (\% weight) on pasture found that the proportions of full guts $(9.17 \mathrm{~kg}$ for $0 \%$ and $6.925 \mathrm{~kg}$ for $2.5 \%$ supplementation), empty guts (2.609 $\mathrm{kg}$ to $2.537 \mathrm{~kg}$ for 0 to $2.5 \%$ supplementation) and gastrointestinal contents $(6.561 \mathrm{~kg}$ to $4.352 \mathrm{~kg}$ for 0 to $2.5 \%$ supplementation) decreased slowly as the level of concentrate supplementation increased.

The abdominal organs, specifically the liver, showed significant differences $(\mathrm{P}<0.05)$ between treatments, and the animals on PEA had heavier livers. These changes may be due to differences in the production of volatile fatty acids in the diets, resulting in hyperplasia and hypertrophy of cellular organelles (Cullen \& MacLachlan, 2001). Moreover, it may be a result of waste and active ingredients of pesticides used in this crop and the grace period, factors that could cause an increased intracellular accumulation of glycogen and/or lipids, leading to an increase in volume and weight of the liver.

The weight of the head and blood collected from the animals did not differ $(\mathrm{P}>0.05)$ among the feed groups. However, Alcalde Aldea \& Sierra Alfranca (1993) state that the size of the head of sheep may be the result of the use of animal as development of the head in males is a secondary sexual characteristic, unlike females, and the older the animal is when slaughtered, the greater the proportional weight of the head.

Frescura et al. (2005) found average values for head weight of $1.013 \mathrm{~kg}$ and $1.31 \mathrm{~kg}$ for blood of crossbred lambs in confinement. Carvalho et al. (2005), working with crossbred animals and different levels of supplementation (\% weight) on pasture and slaughtered at $28 \mathrm{~kg}$, found weight of head of $1.116 \mathrm{~kg}$ and $1.194 \mathrm{~kg}$ for $0 \%$ and $2.5 \%$, supplementation and weight of blood of $1.028 \mathrm{~kg}$ for $0 \%$ and $1.326 \mathrm{~kg}$ for $2.5 \%$ supplementation, similar to the values found in this work.

The weight of the skin of animals fed SAC and PEA differed from other treatments $(\mathrm{P}>0.05)$, perhaps due to increased amount of fat in the carcass that influenced skinning.

In general, the correlations obtained for REA in vivo and carcass post mortem were positive and low. Bueno et al. (2000) reported that rib eye area is of interest, since it has high positive correlation with the amount of muscle in the carcass. Rouse et al. (2000) and Landim et al. (2007) found medium to high correlations between measurements estimated by ultrasound in vivo and those obtained later on the carcass. However, Ribeiro et al. (1999) reported lower correlations between these measures and Leão (2004) found low and negative correlations.

The correlation of the commercial cuts with $\mathrm{HCW}$ and $\mathrm{CCW}$ is positive and ranged from medium to high. It was also high between the weight of the ham and prime rib (0.83), neck (0.71) and belly (0.64) and between neck and belly (0.69), so when one trait increases there is an increase in the other, agreeing with Landim et al. (2007). High positive correlation was observed for eLW and fLW and positive average correlation between weight of the abdominal viscera and fLW. Rosa et al. (2002) reported that the rumen, reticulum, omasum, abomasum, small intestine and large intestine change growth patterns over time, with the longer time taken for finishing lambs, the more developed the gastrointestinal tract and, thus, its relative contribution to live animal weight, leading to a reduction in carcass yield. Menezes (2006), in a study with Santa Inês lambs finished on different pastures, found no differences between the weights of abdominal and thoracic viscera; however, the weight of these components were highly correlated with slaughter weight and $\mathrm{HCW}$.

There were high positive correlations between eLW and fLW and between empty (empty rumen, omasum and reticulum) and full (full omasum and large intestine) guts. With the increase of body weight there is an increase in the viscera weights. A high correlation was observed for weight 
of the abdominal viscera and full rumen (0.84). SantosCruz et al. (2009) noted relatively early development of the omasum, reticulum and rumen in Santa Ines lambs. Liver, abomasum and small and large intestines had negative early growth.

\section{Conclusions}

The forages studied showed low nutritional quality, resulting in poor performance when included at the ratio of $60 \%$ (concentrate) and $40 \%$ (roughage). Heavier carcass weights and noble cuts of meat as well as higher hot carcass yield were obtained in the groups of sheep fed byproduct of pea crop and saccharin as compared with those that receivd coast cross hay and hay made of the shoot of cassava plant, which had higher weights and percentages of abdominal viscera. The use of by-product of pea crop and saccharine can be recommended for feeding lambs during the dry season.

\section{References}

ALCALDE ALDEA, M.J.; SIERRA ALFRANCA, I. Acabado de cordeiros Meridnos extremeños em cabadero: pesos, crescimientos, rendimientos y valor del quinto cuarto. Archivos de Zootecnia, v.42, n.157, p.161-172, 1993.

ARAÚJO, G.L.A.; MOREIRA, J.N.; FERREIRA, M.A. et al. Consumo voluntário e desempenho de ovinos submetidos a dietas contendo diferentes níveis de feno de maniçoba. Revista Ciência Agronômica, v.35, n.1, p.123-130, 2004.

BEZERRA, L.R.; SILVA, A.M.A.; TEIXEIRA, K.V.M. et al. Dietas ajustadas por diferentes sistemas de exigências nutricionais para cordeiros: características de carcaça e cortes comerciais. Revista Brasileira de Saúde e Produção Animal, v.10, n.3, p.740-748, 2009.

BUENO, M.S.; CUNHA, E.A.; SANTOS, L.E. Características de carcaça de cordeiros Suffolk abatidos com diferentes idades. Revista Brasileira de Zootecnia, v.29, n.6, p.1803-1810, 2000.

BUENO, M.S.; CUNHA, E.A.; SANTOS, L.E. Características de carcaça de ovinos Santa Inês abatidos com diferentes idades. Archivos de Zootecnia, v.50, p.33-38, 2001.

CAMPELO, J.E.G.; OLIVEIRA, M.E.; LOPES, L.B. et al. Morfometria e correlações entre as medidas corporais externas de ovinos Santa Inês. In: REUNIÃO ANUAL DA SOCIEDADE BRASILEIRA DE ZOOTECNIA, 39., 2002, Recife. Anais... Recife: Sociedade Brasileira de Zootecnia, 2002. (CD-ROM).

CARDOSO, M.M. Desempenho e características de carcaça de ovinos Santa Inês e seus cruzamentos em sistema intensivo de produção. 2008. 109f. Dissertação (Mestrado em Ciências Animais) - Faculdade de Agronomia e Medicina Veterinária/ Universidade de Brasília, Brasília.

CARVALHO, G.P.; PIRES, A.J.V.; VELOSO, C.M. et al. Desempenho e digestibilidade de ovinos alimentados com farelo de cacau em diferentes níveis de substituição. Ciência Animal Brasileira, v.7, n.2, p.115-122, 2006.

CARVALHO, S.; VERGUEIRO, A.; KIELING, R. et al. Avaliação da suplementação concentrada de pastagens Tifton- 85 sobre os componentes não carcaça de cordeiros. Ciência Rural, v.35, n.2, p.435-439, 2005

COSTA JÚNIOR, G.S.; CAMPELO, J.E.G.; AZEVÊDO, D.M.M.R. et al. Caracterização morfométrica de ovinos da raça Santa Inês criados nas microrregiões de Teresina e Campo Maior, Piaú́. Revista Brasileira de Zootecnia, v.35, n.6, p.2260-2267, 2006.

CULLEN, J.M.; MacLACHLAN, N.J. Liver, biliary system and exocrine pancreas. In: McGAVIN, M.D.; CARLTON, W.W.; ZACHARY, J.F. (Eds.) Thomson's special veterinary pathology. St. Louis: Mosby, 2001. p.81-124.

CUNHA, E.A.; BUENO, M.S.; SANTOS, L.E. Características de cordeiros de raças de core criados intensivamente. 2000. Available at: <www.ovinosbrasil.com>. Accessed on: Nov. 9, 2009.

DANTAS, A.F.; PEREIRA FILHO, J.M.; SILVA, A.M. A. et al. Características da carcaça de ovinos Santa Inês terminados em pastejo e submetidos a diferentes níveis de suplementação. Revista Ciência Agrotecnologia, v.32, n.4, p.1280-1286, 2008.

ELIAS, A.I.; LEZCANO, O.; LEZCANO, P. et al. Review on development of a protein sugar cane enrichent technology through solid state fermentation (saccharine) Cuban Journal of Agricultural Science, v.24, n.1, p.1-12, 1990.

EMBRAPA GADO DE CORTE. Noções de ciência da carne. Available at: <http://www.cnpgc.embrapa.br/publicacoes/doc/doc77/ 03nocoescarne.html> Accessed on: Nov. 13, 2009.

FERNANDES, M.A.M.; MONTEIRO, G.L.A.; POLI, C.E.H.C. et al. Características das carcaças e componentes do peso vivo de cordeiros terminados em pastagem ou confinamento. Acta Scientiarum. Animal Sciences, v.30, n.1, p.75-81, 2008.

FIGUEIREDO, M.P.; SOUZA, L.F.; FERREIRA, J.Q. Cinética da degradação ruminal da matéria seca da haste, da raiz, do feno da parte aérea e da silagem de raiz de mandioca (Manihot esculenta Crantz) tratada com uréia. Brazilian Journal of Veterinary Research and Animal Science, v.43, n.1, p.11-17, 2006.

FRESCURA, R.B.M.; PIRES, C.C.; ROCHA, M.G. et al. Sistemas de alimentação na produção de cordeiros para abate aos $28 \mathrm{~kg}$. Revista Brasileira de Zootecnia, v.34, n.4, p.1267-1277, 2005.

FURUSHO-GARCIA, I.F.; PEREZ, J.R.O.; OLIVEIRA, M.V.M Componentes corporais e órgãos internos de cordeiros Texel $\mathrm{x}$ Bergamácia, Texel x Santa Inês e Santa Inês puros, terminados em confinamento, com casca de café como parte da dieta. Revista Brasileira de Zootecnia, v.32, n.6, suppl.2, p.1992-1998, 2003.

GARCIA, R.; ELIAS, A.I. A note on saccharine inclusion in feeds for lambs under commercial conditions. Cuban Journal of Agricultural Science, v.24, n.3, p.287-298, 1990.

GUSMÃO FILHO, J.D.; TEODORO, S.M.; CHAVES, M.A. et al. Análise fatorial de medidas morfométricas em ovinos tipo Santa Inês. Archivos de Zootecnia, v.58, n.222, p.289-292, 2009.

JARDIM, R.D.; OSÓRIO, J.C.S.; OLIVEIRA, N.M. et al. Caracteristicas produtivas e comerciais de cordeiros da raça corriedale criados em distintos sistemas nutricionais. Revista Brasileira de Agrociência, v.6, n.3, p.239-242, 2000.

LANDIM, A.V.; CASTANHEIRA, M.; FIORAVANTI, M.C.S. et al. Physical, chemical and sensorial parameters for lambs of different groups, slaughtered at different weights. Tropical Animal Health and Production, v.43, n.6, p.1089-1096, 2011.

LANDIM, A.V.; MARIANTE, A.S.; McMANUS, C. et al. Características quantitativas da carcaça, medidas morfométricas e suas correlações em diferentes genótipos de ovinos. Revista Ciência Animal Brasileira, v.8, n.4, p.665-676, 2007.

LEÃO, C.C. Uso do ultra-som na determinação da qualidade de carcaça de ovinos Santa Inês. 2004. 65f. Dissertação (Mestrado em Ciências Agrárias) - Faculdade de Agronomia e Medicina Veterinária/Universidade de Brasília, Brasília.

LOUVANDINI, H.; NUNES, A.G.; McMANUS, C. et al. Desempenho, características de carcaça e constituintes corporais de ovinos Santa Inês alimentados com farelo de girassol em substituição ao farelo de soja na dieta. Revista Brasileira de Zootecnia, v.36, n.3, p.603-609, 2007.

MAGALHÃES, A.L.R.; CAMPOS, J.M.S.; CABRAL, L.S. et al. Cana de açúcar em substituição a silagem de milho em dietas para vacas em lactação: parâmetros digestivos e ruminais. Revista Brasileira de Zootecnia, v.35, n.2, p.591-599, 2006. 
MAIOR JÚNIOR, R.J.S.; CARVALHO, F.F.R.; BATISTA, A.M.V. et al. Rendimento e características dos componentes não-carcaça de ovinos alimentados com rações baseadas em cana de açúcar e uréia. Revista Brasileira de Saúde e Produção Animal, v.9, n.3, p.507-515, 2008.

MELLO, F.A.; SCHIMIDT, V. Caracterização biométrica de caprinos Anglo-Nubianos nascidos no Brasil, no período de 1993 a 2001. Archivos de Zootecnia, v.57, n.220, p.525-535, 2008.

MENEZES, L.F.O. Características estruturais de três gramíneas tropicais e seu efeito no desempenho e características da carcaça de ovinos Santa Inês, durante o período seco. 2006. 61f. Dissertação (Mestrado em Ciências Agrárias) - Faculdade de Agronomia e Medicina Veterinária/Universidade de Brasília, Brasília.

MIGUÉLEZ, E.; ZUMALACÁRREGUI, J.M.; OSORIO, M.T. et al. Carcass characteristics of suckling lambs protected by the PGI "Lechazo de Castilla y León" European quality label: Effect of breed, sex and carcass weight. Meat Science, v.73, p.82-89, 2006.

MÜLLER, L. Normas para avaliação de carcaças e concurso de carcaças de novilhos. Santa Maria: UFSM, 1980. 31p.

NATIONAL RESEARCH COUNCIL - NRC. Nutrient requirements of small ruminants. Washington, 2006. 362p.

NUNES, H.; ZANNINE, M.A.; MACHADO, T.M.M. et al. Alimentos alternativos na dieta dos ovinos: uma revisão. Archivos Latinoamericanos de Poducción Animal, v.15, n.4, p.147-158, 2007.

OLIVEIRA, I.; SILVA, T.J.P.; FREITAS, M.Q. et al. Caracterização do processo de rigor mortis em músculos de cordeiros e carneiros da raça Santa Inês e maciez da carne. Revista Acta Scientiae Veterinariae, v.32, n.1, p.25-31, 2004.

OLIVEIRA, M.V.M.; PÉREZ, R.R.O.; ALVES, L.E. et al. Rendimento de carcaça, mensurações e peso de cortes comerciais de cordeiros Santa Inês e Bergamácia alimentados com dejetos suínos em confinamento. Revista Brasileira de Zootecnia, v.31, n.3, p.1451-1458, 2002 (supl.).

OSÓRIO, J.C.S; OSÓRIO, M.T.M. Produção de carne ovina: técnicas de avaliação in vivo e na carcaça. Pelotas: UFPEL, 2005. 82p.

OSÓRIO, J.C.S.; OSÓRIO, M.T.M.; JARDIM, P.O.C. Métodos para avaliação de carne ovina "in vivo" na carcaça e na carne. Pelotas: Ed. UPEL, 1998. 107p.

PAIM, T.P.; BORGES, B.O.; LIMA, P.M.T. et al. Uso da termografia para avaliar condições ambientais em cordeiros de diferentes grupos genéticos. Ciência Animal Brasileira, v.12, p.48-57, 2011.

PELIZER, H.L.; PONTIERI, H.M.; MORAES, O.I. Utilização de resíduos agroindústrias em processos biotecnológicos como perspectiva de redução do impacto ambiental. Journal of Technology Management \& Innovation, v.2, n.1, p.118-127, 2007.

PEREIRA, M.S.; RIBEIRO, E.L.A.; MIZUBUTI, I.Y. et al. Carcaça e não-componentes da carcaça de cordeiros recebendo polpa cítrica úmida prensada em substituição à silagem de milho. Acta Scientiarum. Animal Sciences, v.29, n.1, p.57-62, 2007.

PERONI, J.A. Características e composição físico química, corporal e da carcaça de bovinos de cinco grupos genéticos, submetidos a alimentação restrita e 'ad libitum'. 1991. 126f. Dissertação (Mestrado em Zootecnia) - Universidade Federal de Viçosa, Viçosa, MG.

PILAR, R.C.; PÉREZ, J.R.O.; SANTOS, C.L. Considerações sobre produção de cordeiros. Lavras: Universidade Federal de Lavras, 2002. 19p.
QUEIROZ, M.A.A.; SUSIN, I.; PIRES, A.V. et al. Desempenho de cordeiros e estimativa da digestibilidade do amido de dietas com diferentes fontes protéicas. Pesquisa Agropecuária Brasileira, v.43, n.9, p.1193-1200, 2008.

RIBEIRO, F.G.; LEME, P.R.; HENRIQUE, E. et al. Correlações entre medidas com ultra-som in vivo e diretamente na carcaça post mortem em bovinos, In: CONGRESSO DE ZOOTECNIA, 9., 1999. Portugal. Anais... Portugal: APEZ, 1999. p.19

ROCHA, E.D.; ANDRADE, V.J.; EUCLIDES FILHO, K. et al. Tamanho de vacas Nelores adultas e seus efeitos no sistema de produção de gado de corte. Arquivo Brasileiro de Medicina Veterinária e Zootecnia, v.55, n.4, p.474-479, 2003.

ROSA, G.T.; PIRES, C.C.; SILVA, J.H.S. et al. Proporções e coeficientes de crescimento dos não-componentes da carcaça de cordeiros e cordeiras em diferentes sistemas de alimentação. Revista Brasileira de Zootecnia, v.31, n.6, p.2290-2298, 2002.

ROUSE, G.H.; GREINER, S.; WILSON, D.E. et al. The use of real time ultrasound to predict live feedlot cattle value. Beef Research Report. Ames: Iowa State University, 2000. p.89-99,

RUIZ, R.M.; CAIRO, J.; MARRERO, D. et al. Consumo y digestibilidad em carneros alimentados con diferentes proporciones de saccharine en el concentrado. Cuban Journal of Agricultural Science, v.24, n.1, p.61-67, 1990.

SANTANA, A.F. Correlação entre peso vivo e medidas corporais em ovinos jovens da Raça Santa Inês. Revista Brasileira de Saúde e Produção Animal, v.1, p.74-77, 2001.

SANTOS, L.C.; PIRES, R.J. Cortes comerciais de cordeiros Santa Inês. In: ENCONTRO MINEIRO DE OVINOCULTURA, 1., 2000, Lavras. Anais... Lavras: UFLA, 2000. p.149-168.

SANTOS-CRUZ, C.L.; PÉREZ, J.R.O.; MUINZ, J.A. et al. Desenvolvimento dos componentes do peso vivo de cordeiros Santa Inês e Bergamácia abatidos em diferentes pesos. Revista Brasileira de Zootecnia, v.38, n.5, p.923-932, 2009.

SAÑUDO, C.; SIERRA, I. Calidad de la canal en la especie ovina. Ovino. Barcelona: ONE Exclusivas S.A., 1986. p.127-153.

SILVA, L.F.; PIRES, C.C. Avaliações quantitativas das proporções de osso, músculo e gordura da carcaça em ovinos. Revista Brasileira de Zootecnia, v.29, n.4, p.1253-1260, 2000.

SILVA SOBRINHO, A.G. Body composition and characteristics of carcass from lambs of different genotypes and ages at slaughter. 1999. 54p. (Post. Doctored in Sheep Meat Production) Massey University, Palmerstron North.

SILVA SOBRINHO, A.G. Criação de ovinos. Jaboticabal: Funep, 2001. 302p.

SILVA, D.J.; QUEIROZ, A.C. Análises de alimentos - métodos químicos e biológicos. Viçosa, MG: Editora UFV, 2006. 235p.

SILVA, N.V.; COSTA, R.G.; MEDEIROS, A,N. et al. Biometria e correlações com características de carcaça de cordeiros Morada Nova alimentados com dietas contendo flor de seda. In: CONGRESSO NORDESTINO DE PRODUÇÃO ANIMAL, 5., 2008, Aracajú. Anais... Aracajú, 2008. (CD-ROM).

SOUZA, L.A.; GARCIA, R.; BRENARDINHO, S.F. et al. Casca de café em dietas de carneiros: Consumo e digestibilidade. Revista Brasileira de Zootecnia, v.33, n.6, p.2170-2176, 2004 (supl.).

SOUZA, E.Q. Análise e segmentação de mercado na ovinocultura do Distrito Federal. 2006. 103f. Dissertação (Mestrado em Agronegócios) - Universidade de Brasília, Brasília.

YÁÑEZ, E.A.; RESENDE, K.T.; FERREIRA, A.C.D. et al. Utilização de medidas biométricas para predizer características de carcaça de cabritos Saanen. Revista Brasileira de Zootecnia, v.33, n.6, p.1564-1572, 2004. 